\title{
Using encounter rates as surrogates for density estimates makes monitoring of heavily-traded grey parrots achievable across Africa
}

\author{
Stuart J. Marsden, Emmanuel Loqueh, Jean Michel Takuo, John A. Hart \\ Robert Abani, Dibié Bernard Ahon, Nathaniel N. D. Annorbah \\ ROBIN JOHNSON and SIMON VALLE
}

\begin{abstract}
Estimating population sizes in the heavily traded grey parrots of West and Central Africa would provide insights into conservation status and sustainability of harvests. Ideally, density estimates would be derived from a standardized method such as distance sampling, but survey efforts are hampered by the extensive ranges, patchy distribution, variable abundance, cryptic habits and high mobility of the parrots as well as by logistical difficulties and limited resources. We carried out line transect distance sampling alongside a simpler encounter rate method at 10 sites across five West and Central African countries. Density estimates were variable across sites, from $0-0.5$ individuals $\mathrm{km}^{-2}$ in Côte d'Ivoire and central Democratic Republic of the Congo to c. $30 \mathrm{~km}^{-2}$ in Cameroon and $>70 \mathrm{~km}^{-2}$ on the island of Príncipe. Most significantly, we identified the relationship between densities estimated from distance sampling and simple encounter rates, which has important applications in monitoring grey parrots: (1) to convert records of parrot groups encountered in a day's activities by anti-poaching patrols within protected areas into indicative density estimates, (2) to confirm low density in areas where parrots are so rare that distance sampling is not feasible, and (3) to provide a link between anecdotal records and local density estimates. Encounter rates of less than one parrot group per day of walking are a reality in most forests within the species' ranges. Densities in these areas are expected to
\end{abstract}

Stuart J. Marsden, Nathaniel N. D. Annorbah and Simon Valle (Corresponding author) School of Science \& the Environment, Manchester Metropolitan University, Chester Street, Manchester M1 5GD, UK. E-mail s.valle@mmu.ac.uk EMmanuel LoQueH Society for the Conservation of Nature in Liberia, Monrovia, Liberia

Jean Michel Takuo Cameroon Biodiversity Conservation Society, Yaoundé, Cameroon

John A. HART Lukuru Foundation, Circleville, Ohio, USA, and Kinshasa, Democratic Republic of the Congo

Robert Abani SOS Nature, Kisangani, Democratic Republic of the Congo

Dibié Bernard Ahon SOS-FORETS, Campus Universitaire d'Abidjan-Cocody, Centre National de Floristique, Côte d'Ivoire

RoBIN Johnson BirdLife International-Africa Partnership Secretariat, Nairobi, Kenya

Received 20 November 2014. Revision requested 7 January 2015

Accepted 31 March 2015. First published online 15 September 2015. be one individual $\mathrm{km}^{-2}$ or lower, and local harvest should be disallowed on this basis.

Keywords Africa, distance sampling, encounter rate, grey parrot, monitoring, population estimates, Psittacidae

To view supplementary material for this article, please visit http://dx.doi.org/10.1017/So030605315000484

\section{Introduction}

D opulation estimates and trends in abundance are essenL tial for the development of coherent conservation and management plans for wild animal species (Primack, 1993; Newson et al., 2008) and form the cornerstones of the IUCN Red List scheme (IUCN, 2001). For species that are harvested from the wild and traded internationally, population monitoring is a legal requirement imposed by CITES (2014). With high numbers of threatened species and limited resources available (James et al., 1999), there is a need for practical, rapid and inexpensive methods to provide usable metrics of animal abundance (Lancia et al., 1994; Carbone et al., 2002).

As a result of habitat alteration and direct exploitation for the pet trade, parrots are one of the most threatened groups of birds (Collar \& Juniper, 1992; Snyder et al., 2000). The grey parrots Psittacus spp., now classified as two species (Collar, 2013), grey parrot Psittacus erithacus (Central Africa to eastern Côte d'Ivoire; Fig. 1) and timneh parrot Psittacus timneh (western Côte d'Ivoire to Guinea-Bissau), have a history of exploitation for national and international trade. During 1982-2001 > 650,000 wild-caught individuals entered international trade (UNEP-WCMC, 2014), with Cameroon being the main exporter and with 367,166 individuals exported legally during 1981-2005 (BirdLife International, 2014). The true size of the harvest (both past and present) may be much higher as mortality within the trade is likely to be high and illegal trade is impossible to monitor. There is concern that harvest levels are unsustainable (CITES, 2006). Both species are categorized as Vulnerable on the IUCN Red List because of numerous anecdotal reports of declines and local extinctions, making population estimation and monitoring a conservation 


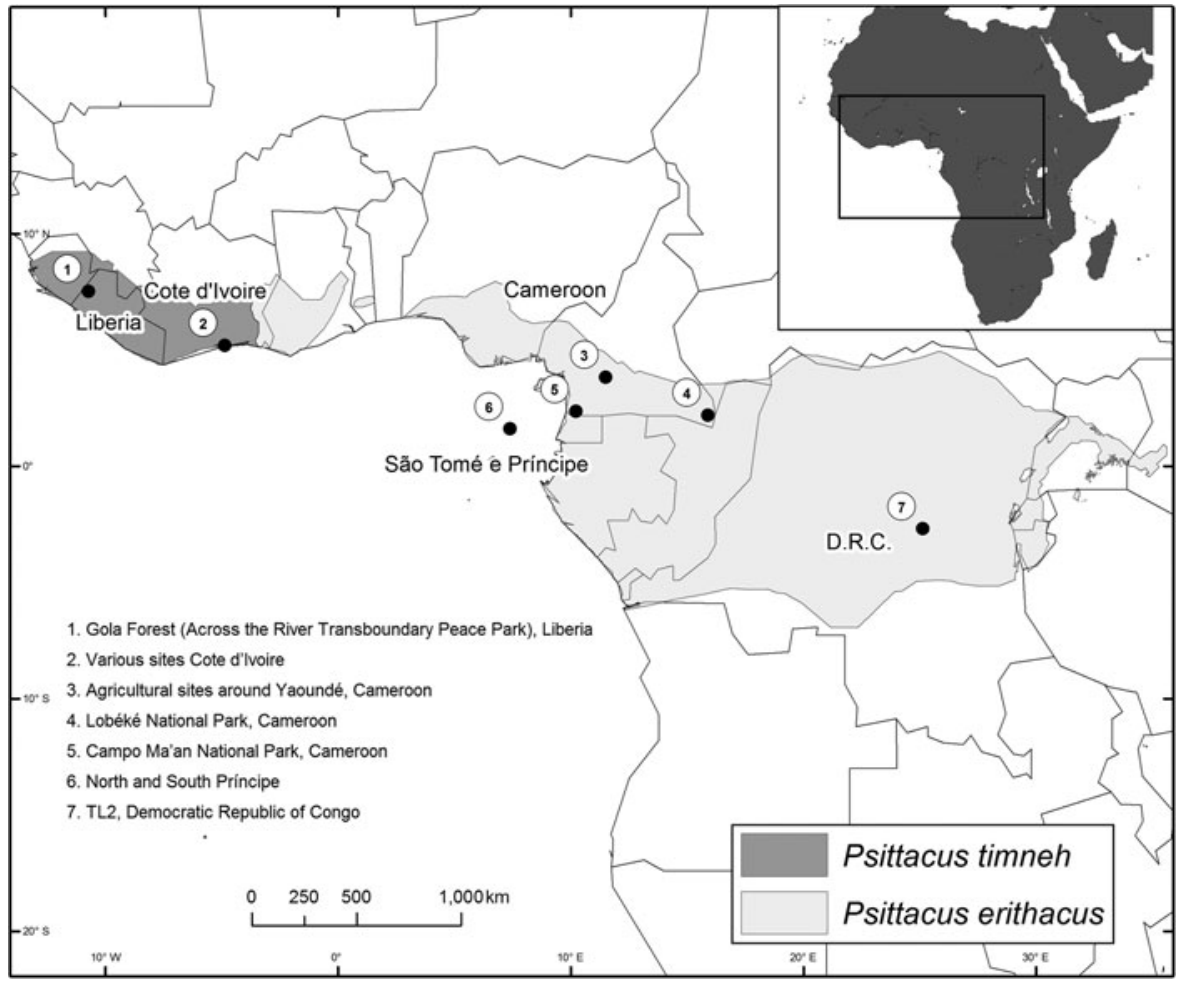

Fig. 1 The ranges of grey Psittacus erithacus and timneh parrots Psittacus timneh in West and Central Africa. priority (BirdLife International, 2013a,b). The species have a vast range, extending over 3 million $\mathrm{km}^{2}$ across Central and West Africa (BirdLife International, 2013a,b). Both species rely largely on forested areas and have presumably been affected by forest loss and degradation, especially in West Africa (Vittek et al., 2014). Their extensive ranges, forest habitat, and patchy distribution present problems of sampling at a sufficient number of sites to produce reliable overall estimates. Despite several attempts, efforts to survey the species accurately have hitherto been hampered by methodological problems, lack of expertise, and the enormity of the task.

Grey parrots, like many other Psittacines, are difficult to survey accurately. They are usually rare (Snyder et al., 2000), occur in complex habitats such as tall rainforest (Lee \& Marsden, 2012), are patchily distributed, cryptic at rest and social in nature, and make long flights between feeding and roosting sites (e.g. Dändliker, 1992a; Juniper \& Parr, 1998). Several methods have been proposed for estimating parrot abundance, including actual counts of rare species, roost counts (Pithon \& Dytham, 1999; Cougill \& Marsden, 2004), simple encounter rates, nest counts, counting along flyways (Amuno et al., 2007), and distance sampling either from points (Marsden, 1999) or transects (Lee \& Marsden, 2012). Distance sampling has dominated efforts in the last 20 years (Casagrande \& Beissinger, 1997; Thomas et al., 2010), and $>80 \%$ of parrot population estimates have been derived using these methods (Marsden \& Royle, 2015). However, distance sampling is timeconsuming and resource-demanding and requires large numbers of perched encounters for precise density estimation (Buckland et al., 2001). Such sample sizes, in the order of 50-80 records, are practically impossible for rare species (Buckland et al., 2008). Thus, parrot conservation would benefit from an easy method of inferring parrot densities, both for rare and common species in a variety of habitats.

We examined the relationship between a simple encounter rate (number of birds or groups per hour), derived from casual walks and stops in the forest, and population density estimates derived for grey parrots at the same sites using line transect distance sampling. If the two were related reasonably strongly, the former might be useful as an acceptable surrogate where the latter is not possible. Although no substitute for more thorough surveys, where these can be undertaken, the use of a simple method could increase our capacity to gauge local grey parrot abundance and track trends, and thus build a profile of the status of the two species as a whole.

\section{Study area}

Data were collected from 10 sites in five countries in West and Central Africa (Fig. 1; Table 1) as part of a CITES/ BirdLife International project on strengthening trade management for the species (CITES, 2013). Fieldwork was centred on areas that were known or suspected to hold reasonable parrot numbers, identified by local BirdLife partners. These were usually within or adjacent to protected areas, with the exception of some fieldwork in agricultural areas with remnant forest patches around Yaoundé, in 
TABLE 1 Study sites in Cameroon, Côte D’Ivoire, DRC and São Tomé \& Príncipe where surveys of grey parrots were conducted, with geographical coordinates, habitat type, survey dates, and the total distance and number of transects surveyed using line transect distance sampling.

\begin{tabular}{|c|c|c|c|c|c|}
\hline Site & Coordinates & Habitats & Dates & $\begin{array}{l}\text { Total } \\
\text { distance } \\
(\mathrm{km})\end{array}$ & $\begin{array}{l}\text { No. of } \\
\text { transects }\end{array}$ \\
\hline \multicolumn{6}{|l|}{ Cameroon } \\
\hline Lobéké National Park (East; Djembe) & $\begin{array}{l}2^{\circ} 11^{\prime} 38^{\prime \prime} \mathrm{N} \\
16^{\circ} 04^{\prime} 07^{\prime \prime} \mathrm{E}\end{array}$ & $\begin{array}{l}\text { Logged forest ( }>15 \text { years } \\
\text { previously) }\end{array}$ & 7-10 July 2013 & 20.0 & 5 \\
\hline Lobéké National Park (West; Djangui) & $\begin{array}{l}2^{\circ} 17^{\prime} 19^{\prime \prime} \mathrm{N} \\
15^{\circ} 38^{\prime} 44^{\prime \prime} \mathrm{E}\end{array}$ & $\begin{array}{l}\text { Logged ( }>15 \text { years) \& } \\
\text { primary forest }\end{array}$ & 10-13 July 2013 & 17.5 & 4 \\
\hline Campo Ma'an National Park (South) & $\begin{array}{l}2^{\circ} 15^{\prime} 36^{\prime \prime} \mathrm{N} \\
9^{\circ} 59^{\prime} 59^{\prime \prime} \mathrm{E}\end{array}$ & $\begin{array}{l}\text { Logged ( }>10 \text { years) \& } \\
\text { primary forest }\end{array}$ & 13-16 Aug. 2013 & 23.5 & 6 \\
\hline Campo Ma'an National Park (North) & $\begin{array}{l}2^{\circ} 27^{\prime} 58^{\prime \prime} \mathrm{N} \\
10^{\circ} 22^{\prime} 26^{\prime \prime} \mathrm{E}\end{array}$ & $\begin{array}{l}\text { Logged ( }>10 \text { years) \& } \\
\text { primary forest }\end{array}$ & 17-20 Aug. 2013 & 18.5 & 4 \\
\hline Agricultural land outside Yaoundé & $\begin{array}{l}3^{\circ} 50^{\prime} 21^{\prime \prime} \mathrm{N} \\
11^{\circ} 30^{\prime} 21^{\prime \prime} \mathrm{E}\end{array}$ & $\begin{array}{l}\text { Agroforestry \& secondary } \\
\text { forest }\end{array}$ & 3-19 July 2013 & 11.3 & 3 \\
\hline \multicolumn{6}{|l|}{ Côte d'Ivoire } \\
\hline $\begin{array}{l}\text { Parc National du Banco; Réserve Dalhia fleur; } \\
\text { Parc National d'Azagny; Zone rurale de Soubré } \\
\text { Democratic Republic of the Congo }\end{array}$ & $\begin{array}{l}5^{\circ} 12^{\prime} 45^{\prime \prime} \mathrm{N} \\
4^{\circ} 52^{\prime} 24^{\prime \prime} \mathrm{W}\end{array}$ & $\begin{array}{l}\text { Primary/secondary forest; } \\
\text { agroforest }\end{array}$ & 7-19 Aug. 2013 & 32 & 7 \\
\hline $\begin{array}{l}\text { TL2 (Tshuapa-Lomami-Lualaba Conservation } \\
\text { Landscape) }\end{array}$ & $\begin{array}{l}2^{\circ} 41^{\prime} 12^{\prime \prime} \mathrm{S} \\
25^{\circ} 08^{\prime} 15^{\prime \prime} \mathrm{E}\end{array}$ & $\begin{array}{l}\text { Primary forest on white } \\
\text { sand }\end{array}$ & 16-26 Aug. 2013 & 108.4 & 7 \\
\hline \multicolumn{6}{|l|}{ São Tomé \& Príncipe } \\
\hline Príncipe North & $\begin{array}{l}1^{\circ} 39^{\prime} 33^{\prime \prime} \mathrm{N} \\
7^{\circ} 23^{\prime} 41^{\prime \prime} \mathrm{E}\end{array}$ & $\begin{array}{l}\text { Secondary forest; } \\
\text { agroforest }\end{array}$ & $\begin{array}{l}16 \text { June-22 Aug. } \\
2012\end{array}$ & 9.9 & 7 \\
\hline Príncipe South & $\begin{array}{l}1^{\circ} 34^{\prime} 33.91^{\prime \prime} \mathrm{N} \\
7^{\circ} 22^{\prime} 32.80^{\prime \prime} \mathrm{E}\end{array}$ & $\begin{array}{l}\text { Primary \& secondary } \\
\text { forest }\end{array}$ & $\begin{array}{l}16 \text { June-22 Aug. } \\
2012\end{array}$ & 9.8 & 7 \\
\hline \multicolumn{6}{|l|}{ Liberia } \\
\hline $\begin{array}{l}\text { Gola forest (across the River Transboundary } \\
\text { Peace Park) }\end{array}$ & $\begin{array}{l}7^{\circ} 32^{\prime} 07^{\prime \prime} \mathrm{N} \\
10^{\circ} 42^{\prime} 60^{\prime \prime} \mathrm{W}\end{array}$ & $\begin{array}{l}\text { Secondary \& logged forest; } \\
\text { agroforest }\end{array}$ & $\begin{array}{l}8 \text { Aug. }-29 \\
\text { Sep. } 2013\end{array}$ & 42.7 & 9 \\
\hline
\end{tabular}

Cameroon, and surveys on Príncipe, which is largely unprotected but which has extensive forest and high numbers of parrots. Two protected areas in Cameroon (Lobéké and Campo Ma'an National Parks) were subdivided into two geographical zones. Details of habitat types, tree sizes and path types used in the surveys are in Supplementary Table S1.

\section{Methods}

At all sites we conducted distance sampling line transects and simple encounter rate surveys in the same areas. Some transects were walked using both methods. Transects were chosen to cover the site as completely as possible and to be representative of the habitats at the site. Transects were not cut especially for the study because of time constraints but were positioned along existing tracks, such as ranger trails and overgrown skid trails. Transects were walked only once for each method. No transect was walked using both methods on the same day, except at one site, TL2 in the Democratic Republic of the Congo (DRC), where we used data from the same transects to calculate both density estimates and encounter rates. Parrots were counted by 1-3 teams of recorders. Surveys were at similar times of year, principally by SM \& JMT (Cameroon; 4 July-19 August 2013), SV (Príncipe; 16 June-22 August 2012), RA (DRC; 8-29 August 2013), DBA (Côte d'Ivoire; 2-29 August 2013), and SM, EB, NA \& SV (Liberia; 8 August-28 September 2013). Recorders were trained and briefed in distance sampling and encounter rate methods prior to the surveys, and all surveys had at least one fieldworker with months of experience with distance sampling (except in Côte d'Ivoire, where no grey parrots were actually recorded).

\section{Line transect distance sampling}

Line transect distance sampling is a well-established survey method for a range of taxa, including parrots (Casagrande \& Beissinger, 1997; Marsden \& Royle, 2015). It involves walking transects of known length and recording, for each encounter, the perpendicular distance from the bird(s) to the transect line. Records from various transects are pooled together and usually DISTANCE is used to model the fall-off in detectability with increasing distance from the transect line 
(Thomas et al., 2010). A number of assumptions are made: that transects are positioned randomly with respect to the bird population; that birds do not move naturally or in response to the observer during the counting process; that distances to objects are known without error (or with small and random error); and, most importantly, that the probability of detecting animals on the transect line is certain (Buckland et al., 2001). This last assumption can be relaxed in some surveys; for example, if the probability of detection at zero metres $\mathrm{g}(\mathrm{o})$ is not certain but is known, or in doubleobserver distance sampling (e.g. Buckland et al., 2010).

Parrots were counted along transects c. 4-6 km long, walked at $1-1.5 \mathrm{~km}$ per hour during $06.30-11.00$ in the absence of rain or strong wind that could affect detectability (Lee \& Marsden, 2012). Parrots were detected both by sight and sound, and their perpendicular distance at first detection was recorded. Surveys were conducted at similar times of year at all sites, corresponding to the non-breeding season in Liberia and other West African countries, including Príncipe, and possibly the onset of breeding in Central Africa (Benson et al., 1988). Only records of perched parrots were included in the analysis because inclusion of flying birds inflates estimates (Marsden, 1999).

DISTANCE v. 6.2 (Thomas et al., 2010) was used to calculate parrot density (individuals $\mathrm{km}^{-2}$ ) at each site. We used the multiple-covariates distance sampling engine, performed with a half-normal key function with cosine adjustment term. Site was included in the analysis as a covariate (Marques et al., 2007) to go some way towards addressing variation in detectability across sites. The best model was selected using Akaike's information criterion (Akaike, 1976) minimization. Parrot sightings were entered as clusters (number in each group), with exact distances rather than in distance bins. The furthest $5 \%$ of distance records were removed (right-hand truncated).

\section{Encounter rates}

Encounter rates have long been used in conservation ecology but are used less often now because of bias associated with variation in detectability across species and habitats, and the need for actual population estimates rather than abundance indices (e.g. Buckland et al., 2008). They involve walking, standing or other detection methods, and counting individuals or groups per hour of recording, unit of distance walked, or mist-net capture effort expended (Lancia et al., 1994).

The teams that carried out distance sampling also collected encounter rate data (number of groups/individuals per hour of searching) in the same areas. Transects walked using line transect distance sampling were surveyed using encounter rates on another day, usually within 2 days and at most 5 days. Path width could be greater using encounter rates than line transect distance sampling, and some encounter rate surveys were carried out along roads. Encounter rate sampling was carried out during 06.3012.00 and 16.00-18.30, and the survey period was less constrained than that used for line transect distance sampling. It is important to restrict distance sampling surveys to periods when birds are most detectable and hence probability of detection close to the transect line (distance $=0 \mathrm{~m}$ ) is most likely to be certain (e.g. Bibby et al., 2000). We extended the survey period for encounter rate surveys to the late afternoon, both to boost sample sizes and to reflect better how encounter rate methods could be used in future parrot surveys.

Recorders could spend variable amounts of time walking or standing; after each half-hour period they recorded whether they were standing still or walking, took a global positioning system reading and made a broad assessment of habitat type (primary forest, secondary forest, agroforest, logged forest, agriculture). Importantly, whereas flying parrots were excluded from line transect distance sampling surveys, records of flying parrots were included in encounter rate calculations. There were two reasons for this. Firstly, our intention was to test whether the encounter rate method could be a useful surrogate for line transect distance sampling in areas of low parrot density. Hence, inclusion of aerial parrots was considered appropriate to maximize sample sizes, especially in areas where parrots are rare. Secondly, surrogate encounter rate methods may, in the future, be undertaken by individuals who are not trained in parrot survey methods. It can be difficult to identify whether parrots (especially those heard only or heard first) are in flight or whether they were flushed or even perched. In parrot surveys proportions of individuals recorded in flight are generally high (Marsden, 1999). In Príncipe the proportion of parrots recorded that were in flight (on transects with $>15$ individuals/groups encountered) was $0.43 \pm \mathrm{SD} 0.28, \mathrm{n}=10$ (S. Valle, unpubl. data).

\section{The relationship between parrot density and encounter rates}

We accumulated line transect distance sampling and comparable encounter rate data from 10 sites (Table 1). We used Spearman's rank correlations to examine the relationship between our density estimates using multiple-covariates distance sampling and encounter rates (groups and individuals), and mean group size across the 10 sites. We then used a reduced/ranged major axis regression (Ryan, 1997) to examine the relationship further. This method is appropriate when both the dependent variable and predictor include errors (Legendre \& Legendre, 1998). We included an intercept in the model as we did not assume that encounter rate is zero when density is zero, as parrots can be recorded 
TABLE 2 Population density estimates calculated using multiple covariates distance sampling with site as a covariate, encounter rates of groups and individuals, and mean group sizes recorded during surveys of grey parrots at 10 sites. Also included are overall population density estimates for Campo Ma'an and Lobéké National Parks, and the island of Príncipe.

\begin{tabular}{|c|c|c|c|c|}
\hline Site & $\begin{array}{l}\text { Density estimate } \pm \mathrm{SE} \\
\text { (individuals } \mathrm{km}^{-2} \text { ) }\end{array}$ & $\begin{array}{l}\text { Encounter rate } \pm \text { SE } \\
\left(\text { groups } h^{-1}\right)\end{array}$ & $\begin{array}{l}\text { Encounter } \\
\text { rate } \pm \mathrm{SE} \\
\text { (individuals } \mathrm{h}^{-1} \text { ) }\end{array}$ & $\begin{array}{l}\text { Mean group } \\
\text { size } \pm \mathrm{SE}\end{array}$ \\
\hline Campo Ma'an South & $14.7 \pm 4.9$ & $0.8 \pm 0.3$ & $2.1 \pm 0.5$ & $4.2 \pm 2.0$ \\
\hline Campo Ma'an North & $7.5 \pm 2.5$ & $1.8 \pm 0.4$ & $5.4 \pm 1.6$ & $2.7 \pm 0.5$ \\
\hline Campo Ma'an National Park & $10.9 \pm 2.9$ & & & \\
\hline Agricultural land near Yaoundé & $4.1 \pm 2.9$ & 1.0 & 2.5 & 2.5 \\
\hline Lobéké East & $40.3 \pm 13.2$ & $2.7 \pm 0.6$ & $6.8 \pm 2.7$ & $2.2 \pm 0.4$ \\
\hline Lobéké West & $21.0 \pm 6.9$ & $2.2 \pm 0.3$ & $3.9 \pm 0.6$ & $1.8 \pm 0.2$ \\
\hline Lobéké National Park & $29.6 \pm 7.7$ & & & \\
\hline Côte d'Ivoire & 0 & 0 & 0 & 0 \\
\hline Gola forest & $2.2 \pm 1.1$ & $0.3 \pm 0.1$ & $0.5 \pm 0.2$ & $1.7 \pm 0.5$ \\
\hline Príncipe North & $76.8 \pm 22.2$ & $6.1 \pm 1.8$ & $14.3 \pm 5.7$ & $1.8 \pm 0.4$ \\
\hline Príncipe South & $35.1 \pm 14.4$ & $5.6 \pm 2.0$ & $13.3 \pm 6.4$ & $1.5 \pm 0.5$ \\
\hline Príncipe island & $53.0 \pm 13.1$ & & & \\
\hline TL2 & $0.4 \pm 0.3$ & $0.1 \pm 0.02$ & $0.2 \pm 0.1$ & $1.5 \pm 0.4$ \\
\hline
\end{tabular}

flying over areas where their on-the-ground density is zero. All analyses were performed in $R$ v. 3.1.2 (R Development Core Team, 2013); the package lmodel 2 was used for the reduced/ranged major axis regression, and the package ggplo2 for plotting the correlation with a 95\% prediction interval.

\section{Results}

Table 2 shows the variability in density estimates and encounter rates across the 10 sites. In Côte d'Ivoire we recorded no parrots along either line transect distance sampling or encounter rate transects $(32 \mathrm{~km}$ and 85 hours, respectively), and our density estimate and encounter rate from DRC were low ( $0.42 \pm$ SE 0.29 individuals $\mathrm{km}^{-2}$ and $0.08 \pm \mathrm{SE} 0.02$ groups $\left.\mathrm{h}^{-1}\right)$. The highest densities were estimated in Príncipe North ( $76.8 \pm \mathrm{SE} 22.2$ individuals $\left.\mathrm{km}^{-2}\right)$, with an encounter rate of $6.0 \pm \mathrm{SE} 1.8$ groups $\mathrm{h}^{-1}$. Densities in Cameroon's protected areas were high, especially in Lobéké National Park, which had the highest density estimate of any site in mainland Africa (29.6 \pm SE 7.7 individuals $\mathrm{km}^{-2}$ ). Overall mean group size was $1.98 \pm \mathrm{SE}$ 0.34, with the largest flock recorded comprising 20 individuals, at Lobéké East.

There was a strong relationship between estimated density and encounter rates of groups $\left(r_{s}=+0.95, \mathrm{n}=10, \mathrm{P}<0.001\right.$; Fig. 2). Encounter rates of groups $h^{-1}$ were strongly correlated with encounter rates of numbers of individuals $\mathrm{h}^{-1}\left(r_{s}=+0.93\right.$, $\mathrm{n}=10, \mathrm{P}<0.01)$ but there was no relationship between density estimates and mean group sizes $\left(r_{s}=+0.29, \mathrm{n}=10\right.$, $\mathrm{P}=0.40)$. The equation for the reduced major axis regression $\left(R^{2}=0.80, \quad \mathrm{df}=9, \quad \mathrm{P}=0.01\right)$ was Encounter rate $=(0.088 \times$ Density $)+0.22$.

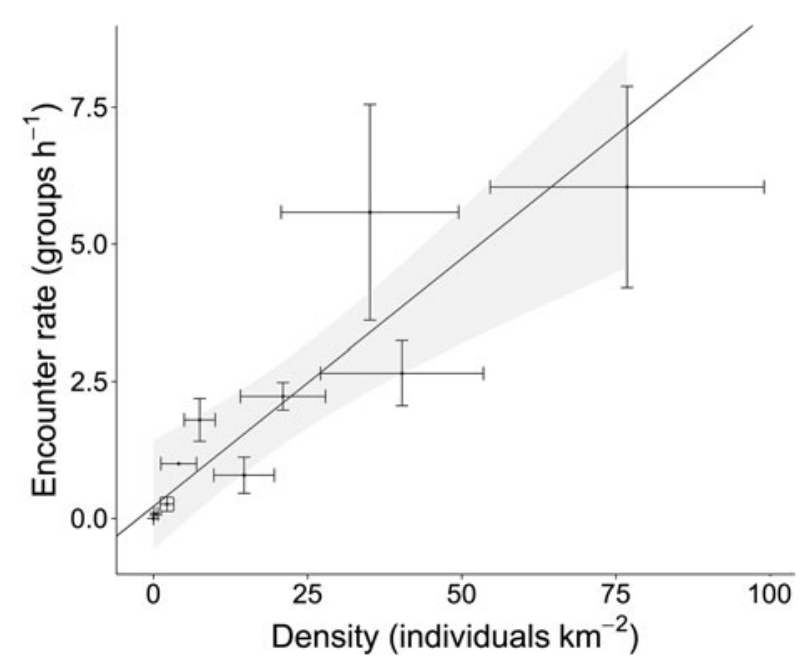

FIG. 2 The relationship between estimates of grey parrot density $( \pm$ SE) and encounter rates $( \pm \mathrm{SE})$, with $95 \%$ prediction region (shaded).

\section{Discussion}

Ideally abundance estimates for species of conservation importance should derive from high-quality data collected during standardized surveys (Sutherland, 2006). Such surveys should accumulate sufficient numbers of records to facilitate precise density estimation (Marsden, 1999), and should account for differences in detectability across sites and species (Buckland et al., 2001). Distance sampling is the method of choice for surveying many tropical birds, and parrots in particular (Marsden \& Royle, 2015), because if it is designed appropriately it takes into account uncontrollable variables that may affect detectability and, in turn, the precision and accuracy of the estimate (Marques 
et al., 2007). However, in many instances distance sampling methods are not an option because there is a lack of the necessary expertise to design and execute the surveys, and analyse the resulting data. Moreover, a lack of economic resources often means that it is impossible to fund extensive and/or repeated surveys and to overcome the logistical difficulties of surveying parrots in large and remote areas. The demonstrated relationship between estimated density and encounter rate means that we can have reasonable confidence in using the latter as a surrogate for the former. Of course, there are a number of issues producing noise in the relationship between the two measures: sites may have varying levels of parrot detectability (Buckland et al., 2001); there is variation in the ability of observers to detect birds, especially at larger distances; parrots may fly more often at some sites than others (Marsden, 1999); and parrot group sizes may vary across sites and seasons (if birds are in larger groups, fewer groups may be encountered for a given population density). Nevertheless, we believe that, as has been found in other situations (e.g. Danielsen et al., 2005), an encounter rate method can be a useful tool, in this case for assessing grey parrot abundance in situations where economic resources and/or distance sampling skills are lacking. Our calibrations apply only to grey parrots; if the method is deemed appropriate for other species, then species- and situation-specific calibrations would need to be done to support the relationship between the more technical survey method and the simpler surrogate.

Under-predicting density using the surrogate method is not as great a problem, in conservation terms, as mistakenly predicting high density. The 95\% prediction region in Fig. 2 shows the degree of uncertainty that could arise from short parrot surveys. Intervals are wide when abundance is high but this is probably not a significant problem as these are the population levels at which distance sampling would be most feasible. Note that an encounter rate of $>1$ group $h^{-1}$, which far exceeds that which would be recorded over much of the species' range, can still be associated with an effective population density of zero. This is because records of flying birds are included in the encounter rate method but not in the density estimates. In effect, density within the sampled area is zero but parrots are recorded flying over the sampled site.

The method will facilitate abundance estimation in situations where parrots are too rare to be surveyed effectively using distance sampling. Our regression indicated that a mean encounter rate of one flying or perched group per hour in forest habitat corresponded to a density estimate of c. ${ }^{10-15}$ individuals $\mathrm{km}^{-2}$. At such densities it is likely that line transect distance sampling will be feasible, but it is in the many areas, especially in West Africa, where parrot densities are much lower, where the value of encounter rate calibration lies. One group per (10-hour) day corresponds to a density of c. one individual $\mathrm{km}^{-2}$, thus some protected areas in Nigeria or Ghana, where one group was encountered per 5-7 days of surveying (Olmos \& Turshak, 2009; F. Dowsett-Lemaire in litt. to BirdLife's Globally Threatened Bird Forums, 27 January 2012), almost certainly hold negligible densities of parrots. The relationship represents a key link between quantitative and anecdotal data, which could be of use in areas where the latter are the only information available. Opportunistic observations by forest guards, birdwatchers or scientists studying other groups could be converted into encounter rates and thus provide the first estimates of population density for many areas. These data could form the basis for identifying protected areas that still hold reasonable numbers of parrots, which could then become the focus of intensive surveys. Where appropriate and feasible, the same technique could be used with historical data, to estimate former abundances and thus serve as a yardstick to measure population trends. The lack of quantitative historical data on grey parrot abundance in many parts of its range has probably hampered efforts to gauge the true extent of declines in the species (Martin et al., 2014).

Carbone et al. (2001) identified a relationship between density and rates of camera-trap capture for tigers Panthera tigris across their range, proposing the latter as a means of inferring the former. The proposal drew criticism concerning the precise calibration of the method, and whether it would be applicable to other species elsewhere (Jennelle et al., 2002). The method needed to be refined using independent data collected using a standardized method (Carbone et al., 2002). Moreover, detectability, and therefore encounter rate, can vary significantly between species, home range sizes and study designs (Sollmann et al., 2013). Despite its limitations, however, the method has been welcomed by researchers as a useful tool for abundance estimation in various species, from large carnivores (e.g. Linkie et al., 2006) and forest ungulates (Rovero \& Marshall, 2009) to ground-dwelling birds (e.g. Samejima et al., 2012). Our approach for grey parrots in Africa was similar, except that our density estimates and encounter rates were not derived using shared data (except for one of the 10 sites, in DRC, where we used the same transects for both density estimates and encounter rates).

An alternative, or complement, to using encounter rates as surrogates for density would be to use occupancy modelling (MacKenzie et al., 2002), either as a stand-alone method to detect changes in abundance or occupancy across sites, or as a surrogate for density estimation. Occupancy modelling is flexible, and relatively quick and easy to perform compared to distance sampling (Zylstra et al., 2010). An alternative could be to identify the relationship between occupancy values and density estimates, and to use the former in place of encounter rates as a surrogate for the latter. Research on the use of occupancy modelling as a general surrogate for estimates of parrot abundance (Berkunsky et al., 2014; Figueira et al., 2015), and especially its value in monitoring 
populations over time at individual sites such as protected areas (e.g. Burton et al., 2012), may be rewarding.

Our results show how variable the abundance of grey parrots is across their ranges. Local availability of food resources and suitable nesting sites are known to be limiting factors for many parrot populations (Newton, 1994; Rowley \& Collar, 1997). Data on the grey parrots are few, but we know they select large trees of certain species to nest in (Dändliker, 1992a; S. Valle, unpubl. data), and that these species, including Terminalia superba and Milicia excelsa, are often targeted by loggers. Although poorly described, competition with other hole-nesting birds may be another factor restricting local abundance (Amuno et al., 2010). Our density estimates for the two parks in Cameroon and for Príncipe exceed previously reported estimates. From roost counts, Dändliker (1992b) estimated densities of just $0.3^{-0.5}$ individuals $\mathrm{km}^{-2}$ in Guinea, and $0.15-2.2 \mathrm{~km}^{-2}$ in Ghana (Dändliker, 1992a); using nest counts McGowan (2001) calculated a density of $4.9-6.0 \mathrm{~km}^{-2}$ in Nigeria. It would be unwise to compare our results with theirs but we suggest that grey parrots still have the potential to live at high densities if conditions are appropriate. Lobéké National Park appears to be currently well-managed and protected, and Príncipe has, at present, low rates of parrot trapping, and much suitable habitat. This is in stark contrast to the near absence of grey parrots from most of Ghana (Marsden et al., 2013) and their rarity in protected areas in Cote d'Ivoire. In these areas and across the majority of their ranges it is difficult to imagine grey parrots being anything other than rare or absent in almost all parts of the landscape in the coming decades.

Related to the above, and whichever survey method is used, it is important to define the site to which the estimate of parrot abundance relates, and to ensure that sampling within that site is representative. Abundance estimates may most often relate to an individual protected area, in which case adequate sampling across its geographical area and habitats is crucial if an overall estimate of abundance for the unit is required (e.g. Bibby et al., 20oo; Buckland et al., 2008). The same is true for longitudinal monitoring of parrot populations at a single site over time. If repeat encounter rate surveys do not use the same transect routes as the original survey, the best we can expect is for this kind of monitoring to provide an early warning of potential problems at the site, which could trigger a more formal line transect distance sampling survey. Likewise, it is important to acknowledge potential issues of transect placement using either line transect distance sampling or encounter rate methods. Surveys along existing ranger/hunter trails or only in accessible parts of the site may be biased in that trapping pressure may be higher, and hence densities lower, in these areas (e.g. Espinosa et al., 2014). A study of avian frugivores in the Philippines found significant differences in both encounter rates and population densities between randomly placed transects, hunter trails and wider access routes (Española, 2013).

With so much variation in abundance across the ranges of the grey parrots, we need various approaches to maximize our knowledge of local and overall abundance. We suggest a hierarchical approach to surveying the two species. In some areas, such as the extensive protected areas in Cameroon and Gabon, line transect distance sampling surveys will be feasible to estimate population sizes. In these cases, use of carefully designed distance sampling surveys is preferable to using encounter rate surveys. The former considers local detectability issues and yields estimates of actual density and precision (Buckland et al., 2008). In the Central African countries, including Gabon and DRC, it may also be possible to add encounter rate data collection to existing surveys, such as those for elephants and apes (e.g. Maisels et al., 2013). In such cases, it is crucial that adding parrots to the list of survey targets does not negatively affect field protocols or search techniques for those species. In short, the ideal surveys for parrots are those tailored specifically for parrots (Marsden, 1999) and performed by properly trained fieldworkers (Nadeau \& Conway, 2012). It is also important to note that areas with high densities of large mammals may not necessarily coincide with those that have high densities of grey parrots, as was borne out by our results from TL2 in DRC (Hart, 2009).

Density estimation in protected areas and other strongholds (either direct or inferred from encounter rates) will form the basis of country-wide population estimates for grey parrots, but encounter rate data from the wider agricultural landscapes across the parrots' range are also needed. In Central Africa, reasonable numbers of parrots are to be expected in some non-protected areas and these may contribute significantly to total population figures. However, in West Africa the situation is different and of greater concern, with grey parrots extirpated from much of the landscape, and populations thriving in only a few areas (BirdLife International, 2014). As the few available data indicate a collapse of both grey and timneh parrot populations from virtually everywhere west of Cameroon (Marsden et al., 2013; Martin et al., 2014), a resumption of legal trade in either species from this region is currently untenable.

\section{Acknowledgements}

Data from Liberia, Côte d'Ivoire, Cameroon and DRC were collected during the BirdLife International African Grey Parrot Pilot Project funded by the Secretariat of CITES. We thank BirdLife Africa Secretariat for coordinating work, and Roger Fotso (WCS Cameroon Country Coordinator) and Nzooh Zacharie (WWF Cameroon) for help facilitating fieldwork. The work on the island of Príncipe was funded by Parrots International and facilitated by Eng. Arlindo 
Carvalho, National General Director of the Environment, Eng. Nestor Umbelina, Secretariat of Infrastructures and the Environment, and Daniel Ramos, Director of the Parque Natural d' Ôbo do Príncipe. HBD kindly provided logistical support during the fieldwork on Príncipe. We thank Nigel Collar and Kariuki Ndanganga for their helpful comments.

\section{References}

Акалке, H. (1976) An information criterion. Mathematical Sciences, $14,5-9$.

Amuno, J.B., Massa, R. \& Dranzoa, C. (2007) Abundance, movements and habitat use by African grey parrots (Psittacus erithacus) in Budongo and Mabira forest reserves, Uganda. Ostrich, 78, 225-231.

Amuno, J.B., Massa, R. \& Oкethowengo, G. (2010) Some observations on nesting African grey parrots, Psittacus erithacus, in Uganda. Rivista Italiana di Ornitologia, 80, 57-59.

Benson, C., Benson, F., Stuart, S. \& Fry, C. (1988) Parrots, parakeets and lovebirds. In The Birds of Africa (eds C. Fry, S. Keith \& E. Urban), pp. 1-25. Academic Press, London, UK.

Berkunsky, I., Cepeda, R.E., Marinelli, C., Simoy, M.V., Daniele, G., Kacoliris, F.P. et al. (2014) Occupancy and abundance of large macaws in the Beni savannahs, Bolivia. Oryx, http://dx.doi.org/10. 1017/So030605314000258

Bibby, C.J., Burgess, N.D., Hill, D.A. \& Mustoe, S.H. (2000) Bird Census Techniques, 2nd edition. Academic Press, London, UK.

Birdife International (2013a) Psittacus erithacus. In The IUCN Red List of Threatened Species v. 2014.3. Http://www.iucnredlist.org [accessed 26 May 2015].

BirdLife International (2013b) Psittacus timneh. In The IUCN Red List of Threatened Species v. 2014.3. Http://www.iucnredlist.org [accessed 26 May 2015].

Birdife International (2014) Grey parrot Psittacus erithacus. Http://www.birdlife.org/datazone/speciesfactsheet.php?id=112657 [accessed 27 May 2015].

Buckland, S.T., Anderson, D.R., Burnham, K.P., Laake, J.L., Borchers, D.L. \& Thomas, L. (2001) Introduction to Distance Sampling: Estimating Abundance of Biological Populations. Oxford University Press, Oxford, UK.

Buckland, S.T., LaAKe, J.L. \& Borchers, D.L. (2010) Double-observer line transect methods: levels of independence. Biometrics, 66, 169-177.

Buckland, S.T., Marsden, S.J. \& Green, R.E. (2008) Estimating bird abundance: making methods work. Bird Conservation International, 18, S91-S108.

Burton, A.C., Sam, M.K., Balangtaa, C. \& Brashares, J.S. (2012) Hierarchical multi-species modeling of carnivore responses to hunting, habitat and prey in a West African protected area. PLoS ONE, 7(5), e38007.

Carbone, C., Christie, S., Conforti, K., Coulson, T., Franklin, N., GinsberG, J.R. et al. (2001) The use of photographic rates to estimate densities of tigers and other cryptic mammals. Animal Conservation, 4, 75-79.

Carbone, C., Christie, S., Conforti, K., Coulson, T., Franklin, N., GinsberG, J.R. et al. (2002) The use of photographic rates to estimate densities of cryptic mammals: response to Jennelle et al., Animal Conservation, 5, 121-123.

Casagrande, D.G. \& Beissinger, S.R. (1997) Evaluation of four methods for estimating parrot population size. The Condor, 99, 445457.
CITES (2006) Twenty-second meeting of the Animals Committee, Lima, Peru. 7-13 July 2006. Http://www.cites.org/eng/com/ac/22/ E22-10-2.pdf [accessed 27 May 2015].

CITES (2013) Strengthening Capacity for Monitoring and Regulation of International Trade of African Grey Parrot. Report prepared by BirdLife Africa Partnership Secretariat, Geneva, Switzerland.

CITES (2014) Convention on International Trade in Endangered Species of Wild Fauna and Flora. Appendices I, II and III. Http:// cites.org/eng/app/appendices.php [accessed 31 October 2014].

Collar, N.J. (2013) Timneh parrot and grey parrot represent two species. Http://stuartmarsden.blogspot.co.uk/2013/12/ timneh-parrot-and-grey-parrot-represent.html [accessed 31 October 2014].

Collar, N.J. \& Juniper, A.T. (1992) Dimensions and causes of the parrot conservation crisis. In New World Parrots in Crisis: Solutions from Conservation Biology (eds S.R. Beissinger \& N.F.R. Snyder), pp. 1-24. Smithsonian Institution Press, Washington, DC, USA.

Cougill, S. \& MARsden, S.J. (2004) Variability in roost size in an Amazona parrot: implications for roost monitoring. Journal of Field Ornithology, 75, 67-73.

Dändliker, G. (1992a) The Grey Parrot in Ghana: A Population Survey, a Contribution to the Biology of the Species, a Study of its Commercial Exploitation and Management Recommendations. A Report on CITES Project S-30. Unpublished report. CITES, Geneva, Switzerland.

Dändliker, G. (1992b) Le Perroquet Gris (Psittacus erithacus) en Guinée. Evaluation des populations, contribution à la biologie, étude de l'exploitation commerciale et recommandations pour la gestion. Report sur le projet CITES S-3o. Unpublished report. CITES, Geneva, Switzerland.

Danielsen, F., Burgess, N.D. \& Balmford, A. (2005) Monitoring matters: examining the potential of locally-based approaches. Biodiversity and Conservation, 14, 2507-2542.

EsPaÑola, C.P. (2013) Ecology and conservation of the parrots of Luzon, Philippines. PhD thesis. Manchester Metropolitan University, Manchester, UK.

Espinosa, S., Branch, L.C. \& Cueva, R. (2014) Road development and the geography of hunting by an Amazonian indigenous group: consequences for wildlife conservation. PLoS ONE, 9(12), e114916.

Figueira, L., Tella, J.L., Camargo, U.M. \& Ferraz, G. (2015) Autonomous sound monitoring shows higher use of Amazon old growth than secondary forest by parrots. Biological Conservation, $184,27-35$.

Hart, T. (2009) A New Conservation Landscape for Bonobo: Discovery and Conservation of the Tshuapa-Lomami-Lualaba Landscape in the Democratic Republic of Congo. Lukuru Wildlife Research Foundation, Inc., U.S. Fish and Wildlife Service, Washington, DC, USA.

IUCN (2001) IUCN Red List Categories and Criteria. Version 3.1. IUCN Species Survival Commission, Gland, Switzerland and Cambridge, UK.

James, A.N., Gaston, K.J. \& Balmford, A. (1999) Balancing the Earth's accounts. Nature, 401, 323-324.

Jennelle, C.S., Runge, M.C. \& MacKenzie, D.I. (2002) The use of photographic rates to estimate densities of tigers and other cryptic mammals: a comment on misleading conclusions. Animal Conservation, 5, 119-120.

Juniper, T. \& Parr, M. (1998) Parrots: A Guide to Parrots of the World. Pica Press, Robertsbridge, UK.

Lancia, R.A., Nichols, J.D. \& Pollock, K.H. (1994) Estimating the number of animals in wildlife populations. In Research and Management Techniques for Wildlife and Habitats (ed. T.A. Bookhout), pp. 215-253. The Wildlife Society, Bethesda, USA. 
Lee, A.T.K. \& Marsden, S.J. (2012) The influence of habitat, season, and detectability on abundance estimates across an Amazonian parrot assemblage. Biotropica, 44, 537-544.

Legendre, P. \& Legendre, L. (1998) Numerical Ecology, 2nd edition. Elsevier, Amsterdam, The Netherlands.

Linkie, M., Chapron, G., Martyr, D.J., Holden, J. \& LeaderWilliams, N. (2006) Assessing the viability of tiger subpopulations in a fragmented landscape. Journal of Applied Ecology, 43, 576-586.

MacKenzie, D.I., Nichols, J.D., Lachman, G.B., Droege, S., Royle, J.A. \& Langtimm, C.A. (2002) Estimating site occupancy rates when detection probabilities are less than one. Ecology, 83 , 2248-2255.

Maisels, F., Strindberg, S., Blake, S., Wittemyer, G., Hart, J., Williamson, E.A. et al. (2013) Devastating decline of forest elephants in central Africa. PLoS ONE, 8(3), e59469.

Marques, T.A., Thomas, L., Fancy, S.G. \& Buckland, S.T. (2007) Improving estimates of bird density using multiple-covariate distance sampling. The Auk, 124, 1229-1243.

Marsden, S.J. (1999) Estimation of parrot and hornbill densities using a point count distance sampling method. Ibis, 141, 327-39o.

Marsden, S.J., Collar, N.J. \& WaUgh, D. (2013) Zusammenbruch der Graupapageienbestände in Ghana. Papageien, 12, 425-429.

Marsden, S.J. \& Royle, K. (2015) Abundance and abundance change in the world's parrots. Ibis, 157, 219-229.

Martin, R.O., Perrin, M.R., Boyes, R.S., Abebe, Y.D., Annorbah, N.D., Asamoah, A. et al. (2014) Research and conservation of the larger parrots of Africa and Madagascar: a review of knowledge gaps and opportunities. Ostrich, 85, 205-233.

McGowan, P. (2001) Status, Management and Conservation of the African Grey Parrot Psittacus erithacus in Nigeria. CITES, Geneva, Switzerland.

Nadeau, C.P. \& Conway, C.J. (2012) Field evaluation of distance-estimation error during wetland-dependent bird surveys. Wildlife Research, 39, 311-320.

Newson, S.E., Evans, K.L., Noble, D.G., Greenwood, J.D.D. \& Gaston, K.J. (2008) Use of distance sampling to improve estimates of national population sizes for common and widespread breeding birds in the UK. Journal of Applied Ecology, 45, 1330-1338.

Newton, I. (1994) The role of nest sites in limiting the numbers of hole-nesting birds: a review. Biological Conservation, 70, 265-276.

Olmos, F. \& Turshak, L. (2009) A survey of birds in Omo Forest Reserve, south-western Nigeria. African Bird Club Bulletin, 16, 184196.

Pithon, J. \& Dytham, C. (1999) Census of the British ring-necked parakeet Psittacula krameri population by simultaneous counts of roosts. Bird Study, 46, 112-115.

PRIMACK, R.B. (1993) Essentials of Conservation Biology. Sinauer Associates, Sunderland, USA.
R Development Core Team (2013) R: A Language and Environment for Statistical Computing. R Foundation for Statistical Computing. Vienna, Austria.

Rovero, F. \& Marshall, A.R. (2009) Camera trapping photographic rate as an index of density in forest ungulates. Journal of Applied Ecology, 46, 1011-1017.

Rowley, I. \& Collar, N. (1997) Order psittaciformes. In Handbook of Birds of the World. Vol. 4, Sandgrouse to Cuckoos (eds J. del Hoyo, A. Elliot \& J. Sartagal), pp. 246-477. Lynx Edicions, Barcelona, Spain.

Ryan, T.P. (1997) Modern Regression Methods. Wiley, New York, USA. Samejima, H., Ong, R., Lagan, P. \& Kitayama, K. (2012)

Camera-trapping rates of mammals and birds in a Bornean tropical rainforest under sustainable forest management. Forest Ecology and Management, 270, 248-256.

Snyder, N.F.R., McGowan, P., Gilardi, J.D. \& Grajal, A. (2000) Parrots: Status Survey and Conservation Action Plan 2000-2004. IUCN, Gland, Switzerland and Cambridge, UK.

Sollmann, R., Mohamed, A., Samejima, H. \& Wilting, A. (2013) Risky business or simple solution-relative abundance indices from camera-trapping. Biological Conservation, 159, 405-412.

Sutherland, W.J. (ed.) (2006) Ecological Census Techniques: A Handbook, 2nd edition. Cambridge University Press, Cambridge, UK.

Thomas, L., Buckland, S.T., Rexstad, E.A., Laake, J.L., STrindberG, S., Hedley, S.L. et al. (2010) Distance software: design and analysis of distance sampling surveys for estimating population size. Journal of Applied Ecology, 47, 5-14.

UNEP-WCMC (2014) CITES trade database. Http://trade.cites.org/ [accessed 13 March 2015].

Vittek, M., Brink, A., Donnay, F., Simonetti, D. \& Desclée, B. (2014) Land cover change monitoring using Landsat MSS/TM satellite image data over West Africa between 1975 and 1990. Remote Sensing, 6, 658-676.

Zylstra, E.R., Steidl, R.J. \& Swann, D.E. (2010) Evaluating survey methods for monitoring a rare vertebrate, the Sonoran desert tortoise. The Journal of Wildlife Management, 74, 1311-1318.

\section{Biographical sketches}

STUART MARSDEN's research interests lie in the effects of human processes on wildlife, especially tropical birds such as parrots. Emmanuel Loqueh, Jean Michel Takuo, John Hart, Robert Abani and Dibié Ahon work closely with BirdLife International in West and Central Africa, on various bird conservation projects. Nathaniel Annorbah and Simon Valle are researching population trends and dynamics and the sustainability of trade in grey parrots. ROBIN JOHNSON has managed several conservation and livelihood projects on birds and other wildlife across Africa. 